\title{
Microbiology Research Journal International
}

20(5): 1-14, 2017; Article no.MRJI.33842

ISSN: 2456-7043

(Past name: British Microbiology Research Journal, Past ISSN: 2231-0886, NLM ID: 101608140)

\section{A Brief Review of Oyster-associated Microbiota}

\author{
Zhen $\mathrm{Li}^{1}$, Verona V. Nicolae ${ }^{2}$, Raji Akileh ${ }^{3}$ and Tuoen $\mathrm{Liu}^{3^{*}}$ \\ ${ }^{1}$ Washington State Department of Health, Public Health Laboratories, Shoreline, WA 98155, USA. \\ ${ }^{2}$ Department of Biological Sciences, Idaho State University, Pocatello, ID 83209, USA. \\ ${ }^{3}$ Department of Biomedical Sciences, West Virginia School of Osteopathic Medicine, Lewisburg, \\ West Virginia 24901, USA.
}

\section{Authors' contributions}

This work was carried out in collaboration between all authors. Author $Z L$ wrote the first draft and revisions of the manuscript. Author VVN wrote the first draft of the manuscript, author RA wrote revisions of the manuscript and author TL wrote the first draft and revisions of the manuscript. All authors read and approved the final manuscript.

Article Information

DOI: $10.9734 / M R J I / 2017 / 33842$ Editor(s):

(1) Joao Lucio Azevedo, Department of Genetics, University of Sao Paulo, Escola Superior de Agricultura "Luiz de Queiroz" (ESALQ / USP), Sao Paulo, Brazil.

(2) Giuseppe Blaiotta, Department of Food Science, Via Università, Italy. Reviewers:

(1) Froelich Brett, The University of North Carolina at Chapel Hill, USA (2) Wagih Mommtaz Ghannam, Mansoura University, Egypt. (3) Ionica Mihaela lancu, Banat University of Agronomical Sciences and Veterinary Medicine, Romania. (4) Giuseppe Gregori, Local Health Unit, Italy. Complete Peer review History: http://www.sciencedomain.org/review-history/19912

Mini-review Article

Received $1^{\text {st }}$ May 2017

Accepted $3^{\text {rd }}$ July 2017

Published $7^{\text {th }}$ July 2017

\section{ABSTRACT}

Oysters are important mariculture species worldwide. Because of their filter-feeding behaviors, oysters contain complicated microbial populations, and these varying microbial populations can provide a correlation to increased oyster mortalities in the oyster farming industry as well as food outbreaks associated with public health surveillance. This review summarizes the significant outcomes in oyster microbiota research, including the identified oyster-associated bacterial taxa and comparison of different oyster tissues for microbial studies. In addition, environmental factors that could potentially affect the dynamics of oyster microbiota are discussed. Recent approaches developed to study oyster microbiota as well as their limitations are also highlighted in this review. Finally, future directions in oyster microbiota research have been suggested.

Keywords: Oyster; bacteria; microbiota; next-generation sequencing; pathogens. 


\section{INTRODUCTION}

Oyster farming is an important component of global mariculture economy. Oyster reefs are also a main structural component of many estuaries, providing not only a reef habitat for marine ecosystems, but also construction materials used for human civilizations [1].

Many oyster species have been studied in aquaculture and food research due to their important relationship to public health worldwide. The most common types of oysters which have been well investigated include the Pacific oyster (Crassostrea gigas), Eastern oyster (Crassostrea virginica), Sydney rock oyster (Saccostrea glomerata), European flat oyster (Ostrea edulis), Portuguese oyster (Crassostrea angulata), Chilean oyster (Tiostrea chilensis), Indo-Pacific oyster (Chama pacifica and Chama savignyi), Slipper oyster(Crassostrea iredalei), Cortez oyster (Crassostrea corteziensis), and Kumamoto Oyster (Crassostrea sikamea) [2-10]. The globally distributed $C$. gigas is the most popular species in oyster aquaculture, primarily due to its relatively faster growth rate than any other oyster species (Spp.) [11].

One of the major obstacles in oyster aquaculture, which significantly influences the number of live oysters, are the factors that lead to the mass summer mortality of $C$. gigas. A variety of countries around the globe, such as Japan [12,13], United States [14-16], France [17], Ireland [18], and Italy [19], have reported a declining population of this species of oyster. Mortality of $C$. gigas population is associated with multiple factors including variable temperature $[16,18,20]$, dissolved oxygen levels [21], reproduction stress [18], phytoplankton blooms [16], as well as viral $[16,19,20,22-24]$ and bacterial infections $[19,23,24]$.

Due to benthic feeding habits and filtration system of oysters, multiple coexistent microbial species can invade and accumulate within their tissues $[6,25]$. There is a possible link that the accumulation of these microbial species may play an important role in increasing the rate of oyster morality. For instance, studies have found that several Vibrio spp. related to oyster mortality outbreaks were detected not only in oysters in a state of moribund, but also in healthy oysters $[24,26]$. Particularly, in France, Chlamydia-like organisms related to Chlamydia psittaci (which were detected and isolated from $C$. gigas) were found to be the major cause of tissue lesions and mortalities in $C$. gigas [27]. In addition, there have been reports that Chlamydia and Mycoplasma bacterial species were responsible for the damage of crucial structures and the causation of diseases in oysters [26].

Bacteria that can cause human illness were also discovered and identified in various species of oysters. Some Vibrio spp., especially Vibrio vulnificus and Vibrio parahaemolyticus, which are well-known pathogens in the causation of human illness, were found in oysters and contributed to disease outbreaks in the United States (U.S.) [28-30]. Other bacterial strains of Salmonella [31, 32 ] and $E$. coli have been detected in oysters in a variety of regions worldwide [33]. Moreover, mercury-resistant bacteria could enhance the intake of mercury $(\mathrm{Hg})$ in oyster species such as C. virginica [34]. Other heavy metals, such as zinc $(\mathrm{Zn})$, copper $(\mathrm{Cu})$, cadmium $(\mathrm{Cd})$ and lead $(\mathrm{Pb})$ have also been detected in oysters [4].

Although the presence of bacteria and heavy metals found in oyster are associated with food poisoning and increasing rates of oyster mortality, investigations on the use of probiotic strains has revealed hope. A study by Karim et al. showed that implementation of probiotic bacterial strains gave the potential to reduce the rate of mortality in larvae and juvenile oysters [35]. Thus, focusing attention towards examining the microbiota in the different life stage of oysters (such as larvae, juvenile and adult oysters) could help to elucidate the interaction between pathogenic and probiotic bacterial strains, which could eventually provide a benefit to the oyster industry and public health authorities.

\section{MAJOR BACTERIAL TAXA IN OYSTER MICROBIOTA}

Several major bacterial phyla have been identified from the microbiota in several different oyster species. Among all the oyster microbiota, Proteobacteria are the most abundant, followed by Firmicutes and Bacteroidetes (Table 1). Several classes of the Proteobacteria phylum have been identified, including Alpha-, Beta-, Gamma-, and Epsilonproteobacteria. Alphaproteobacteria were found to be dominant in some oyster species. The paramyxean parasite Marteiliasy dneyi infected Sydney rock oysters $S$. glomerata were dominated by Rickettsiales-like Alphaproteobacteria spp. [36]. Disease-affected juvenile oysters $C$. virginica were dominated by Roseobacter spp., while noninfected oysters were mainly colonized by a Stappiastellulata-like strain, which both belong to the Alphaproteobacteria class [37]. 
Betaproteobacteria Burkholderia cepacia was the most abundant bacterial specie in $C$. gigas and C. corteziensis [38]. B. cepacia colonizes the post-larval phase of oysters and stably maintains its presence within tissues regardless of growing site changes. The Gammaproteobacteria Vibrio and Pseudomonas were the commonly found genera in several oyster species by in vitro culture [39-42]. In C. gigas residing in Mexico, Gammaproteobacteria were found to be abundant in their gill tissue, gonads and digestive glands [43]. The use of 16S rDNA cloning method revealed that Gammaproteobacteria and the order of Oceanospirillales dominated in gill tissues of Indo-Pacific oyster C. pacifica and C. savignyi [5]. The Gammaproteobacteria Shewanella putrifaciens were found to be the dominant bacterial species in oyster $C$. iredalei in Malaysia using culturing methods [4]. Epsilonproteobacteria Arcobacter-related strains were the most abundant bacterial species found in the $T$. chilensis homogenate by the $16 \mathrm{~S}$ rDNA cloning method [3]. Arcobacter spp. were also found in moribund C. gigas [10]. In addition to oysters, Proteobacteria were also found to be dominant among the microbiota of other shellfish species such as mussels $[9,30]$, indicating that Proteobacteria could be one of the most common residents in shellfish microbiota. Thus, it is vital to reveal the composition and potential functions of Proteobacteria in oyster microbiota, which could be utilized to understand the oyster-related outbreaks.

Bacteroidetes and Firmicutes were also found to be the most common phyla besides Proteobacteria in the microbiota of many oyster species. Other phyla including Actinobacteria, Cyanobacteria, Spirocheates and Chlamydia were highly abundant in multiple species such as C. gigas, C.corteziensis, and C.sikamea, but not so much in other oyster species (Table 1). Due to the abundance of microbial phyla found in oyster microbiota, future studies should also focus on revealing the potential functions of these phyla in different oyster tissues as well as species.

The surrounding environment could influence the abundant taxa even within the same oyster specie. A study analyzing the stomach and gut microbiomes of $C$. virginica from coastal Louisiana, U.S. revealed that Mollicutes (mostly related to Mycoplasma) were the major gut microbiota in C. virginica in Barataria Bay, whereas Planctomycetes were the dominating microbiota found in C. virginica in Lake Caillou [6]. This study indicated that environment variables (such as temperature salinity, phytoplankton and bacterioplankton regimes) could be a potential factor in the determination of microbial species found in Mollusks such as oysters.

\section{PUTATIVE CORE MICROBIOTA}

Microbiota plays a critical role in inhibiting pathogen colonization and in the maintenance of a homeostatic state in oysters. Identification of core microbiota in oysters remains a challenge nowadays due to multiple factors such as different growth phases and conditions of oysters. Bacterial species in oysters can be divided into two major categories: Core (autochthonous) bacteria and transient (allochthonous) bacteria. Core microbiota contain bacteria that are vital to food digestion and pathogen defense [42,44]. Transient microbes are generally influenced by the water column in the environment, thus, total bacterial diversity in oysters could be overestimated because of the existence of transient microbes [38]. One way to efficiently identify the microbiota composition is oyster depuration, which could possibly reduce the amount of transient bacteria in oyster microbiota $[9,38]$. However, transient bacteria has the potential to turn into residential microbiota during oyster larval development, which makes it difficult to interpret the hostbacterial symbiotic relationship [9]. Core microbiota could be estimated by identifying shared microbial taxa among different microbiota samples $[6,45]$. However, elucidating core oyster microbiota would require establishing a commonly accepted standard for defining core operational taxonomic units (OTUs) and collaborating with different oyster research groups to obtain meaningful data to use. Establishment and maintenance of an oyster microbiota database would an additional necessary consideration to further categorize oyster-related microbial species.

\section{POTENTIAL FUNCTIONS OF OYSTER MICROBIOTA}

The understood of functional contributions of oyster microbial populations in oyster growth and development remains limited due to the complexity of microbiota in oysters. Studies have shown that oyster microbiota contain bacteria have functions in assisting their hosts for food digestion. Certain oyster gut bacterial species belonging to Proteobacteria phylum can degrade cellulose and agar from phytoplankton; Other 
Proteobacteria species have the ability to fix nitrogen in bivalves $[9,46]$, promoting the food digestion by host oysters. In addition, some marine Gammaproteobacteria such as Pseudoalteromonas spp. can aid in the degradation of algae, which is an important food resource for oysters [47,48]. With similar functions to Pseudoalteromonas spp., some other bacteria in the marine environment such as Bacteroidetes are capable of assisting in the degradation of algae cell wall components $[9,49]$. In addition to their supportive role in oysters nutritional intake and digestion, oyster microbiota could also provide protection against pathogenic bacteria. For example, multiple studies have showed that Betaproteobacteria cepacia could possibly inhibit pathogenic Vibrio alginolyticus and Vibrio harveyi in oysters [9,50]. With the development of new analytical techniques in microbial studies, further insight into the functionality of the oyster microbiota could be elucidated. Study of the microbial functions in other types of shellfish could also be useful to understand the functions of similar microbes in oysters.

\section{OYSTER MICROBIOTA DIFFERENT OYSTER TISSUES}

Due to their filter-feeding behavior and semiopen circulatory system, oysters could contain microbes that take up residence in many different tissue types. Oyster microbiota have been analyzed from several types of tissue samples, including gill, stomach, intestine, hemolymph, mantle fluid and whole oyster homogenate (listed in Table 1).

Oyster gills can not only aid in respiration, but also have important functions in feeding and reproduction [51]. Due to its functions in respiration and feeding, the gill is one of the major organs in oysters that contains diverse microbial species [43,44]. Furthermore, gill microbiota could be different from those resident microbiota found in other oyster tissues [5]. Due to the relatively large surface area available to the surrounding seawater, gill tissue is a viable choice of tissue for the surveillance of pathogenic organisms found in oysters [44,52]. The studies of gill microbiota have been extensively investigated, and the comparisons of major bacterial phyla identified from different oyster microbiota studies are summarized in Table 1. However, due to the presence of a large amount of host DNA in the microbial DNA isolated from oyster gill tissues, using a 16S rDNA metagenomics approach would be necessary to detect microbial diversity. Moreover, expertizing in the dissection of oyster gills and isolation of microbial DNA requires professional and extensive training, which limits the use of oyster gills in oyster microbiota studies.

In addition to oyster gills, gastrointestinal tissues (such as stomach, intestine and digestive diverticula) are common residential tissues for microbes, and these tissues are commonly used to study oyster microbiota as well (Table 1). Due to the filter-feeding behavior of oysters, their gastrointestinal tissues can contain various transient bacteria and other opportunistic pathogens from their food sources in addition to their core microbiota. Furthermore, King et al. showed that $C$. virginica digestive gland microbiota were diverse and largely unknown [6]. Oyster gastrointestinal tissues could be probed to compare the oyster microbiota from different growing geographical regions across species, as well as microbiome changes caused by seasonal nutrient fluctuations. In addition, oyster gastrointestinal tissues could also be investigated to compare microbiota differences between oyster tissues and surrounding water, which could be useful for understanding bacteria colonization in oyster digestive systems. Studying the potential functions of microbes in oyster gastrointestinal tissues could also provide additional information on their roles in food digestion and nutrition absorption.

In addition to gills and gastrointestinal tissues, oyster hemolymph and mantle fluid also contains diverse microbiota (Table 1). Mantle fluid immerses the gills and other tissues within oyster shells [53]. Due to its rich microbial content $[10,54,55]$ and relatively easy to be accessed, oyster hemolymph has been used to study host immune response to microbial pathogens [56]. Diverse populations of Vibrio spp. have been detected from $C$. gigas hemolymph using culturing methods [56]. Comparing findings from hemolymph to other solid tissues, oyster hemolymph could be the most promising component to study oyster microbiota and possibly contribute to the development of some innovative detection methods. Hemolymph from the oyster semi-open circulatory system can be easily extracted from the sinus of the adductor muscle via syringe needles [54,56,57], thus, sampling hemolymph could avoid shucking and dissecting oysters, which can provide a continuous assessment of microbiota from the same oysters during the course of study or research [10]. 
Table 1. Comparison of major bacterial phyla identified from different oyster microbiota studies in reverse chronological order

\begin{tabular}{|c|c|c|c|c|c|c|}
\hline $\begin{array}{l}\text { Oyster } \\
\text { species }\end{array}$ & Tissue types & $\begin{array}{l}\text { High abundance } \\
\text { phyla }\end{array}$ & Low abundance phyla & Location & Identification methods & References \\
\hline C. gigas & Hemolymph & $\begin{array}{l}\text { Proteobacteria, } \\
\text { Bacteroidetes }\end{array}$ & $\begin{array}{l}\text { Actinobacteria, } \\
\text { Cyanobacteria, Firmicutes, } \\
\text { Fusobacteria, Spirochaetes, } \\
\text { Tenericutes }\end{array}$ & Germany & $\begin{array}{l}\text { Pyrosequencing V3-V5 } \\
\text { regions of the } 16 S \text { rDNA } \\
\text { gene using the GS-FLX } \\
\text { Sequencer }\end{array}$ & {$[10]$} \\
\hline $\begin{array}{l}\text { C. gigas } \\
\text { C. corteziensis } \\
\text { C. sikamea }\end{array}$ & $\begin{array}{l}\text { Depurated post-larvae } \\
\text { homogenate } \\
\text { Depurated adult } \\
\text { oyster gastrointestinal } \\
\text { tissues }\end{array}$ & $\begin{array}{l}\text { Proteobacteria, } \\
\text { Bacteroidetes, } \\
\text { Actinobacteria, } \\
\text { Firmicutes, and } \\
\text { Chlamydia }\end{array}$ & $\begin{array}{l}\text { Fusobacteria, Tenericutes, } \\
\text { Acidobacteria, Chlorobi, } \\
\text { Deinococcus-Thermus, } \\
\text { Spirochaetes, Thermotogae, } \\
\text { and Verrucomicrobia }\end{array}$ & Mexico & $\begin{array}{l}\text { Pyrosequencing V3-V5 } \\
\text { regions of the } 16 S \text { rDNA } \\
\text { gene using the FLX-Junior } \\
\text { Sequencer }\end{array}$ & [9] \\
\hline C. virginica & $\begin{array}{l}\text { Tissues, gut and } \\
\text { mantle fluid }\end{array}$ & Cyanobacteria & - & $\begin{array}{l}\text { Gulf of } \\
\text { Mexico, } \\
\text { Florida, USA }\end{array}$ & $\begin{array}{l}\text { Roche } 454 \mathrm{FLX} \\
\text { pyrosequencing the V4 } \\
\text { region of the 16S rDNA gene }\end{array}$ & {$[25]$} \\
\hline $\begin{array}{l}\text { C. gigas } \\
\text { S. glomerata }\end{array}$ & Homogenate & $\begin{array}{l}\text { Proteobacteria, } \\
\text { Tenericutes, } \\
\text { Spirochaetes }\end{array}$ & - & $\begin{array}{l}\text { South } \\
\text { Australia, } \\
\text { Australia }\end{array}$ & $\begin{array}{l}\text { Pyrosequencing the } \mathrm{V} 1-\mathrm{V} 3 \\
\text { region of the } 16 \mathrm{~S} \text { rDNA gene }\end{array}$ & {$[8]$} \\
\hline C. gigas & $\begin{array}{l}\text { Gill, digestive glands, } \\
\text { and residual tissues } \\
\text { (mantle and adductor } \\
\text { muscle) }\end{array}$ & $\begin{array}{l}\text { Proteobacteria, } \\
\text { Bacteroidetes, } \\
\text { Verrucomicrobia, }\end{array}$ & $\begin{array}{l}\text { Actinobacteria, Fusobacteria, } \\
\text { Acidobacteria, Firmicutes, } \\
\text { Nitrospirae }\end{array}$ & China & $\begin{array}{l}\text { 16S rDNA PCR amplification } \\
\text { and DGGE analysis }\end{array}$ & {$[44]$} \\
\hline C. gigas & Gill tissue & $\begin{array}{l}\text { Proteobacteria, } \\
\text { Bacteroidetes, } \\
\text { Planctomycetes, } \\
\text { Firmicutes, } \\
\text { Tenericutes }\end{array}$ & $\begin{array}{l}\text { Actinobacteria, } \\
\text { Cyanobacteria, Fusobacteria, } \\
\text { Spirochaetes }\end{array}$ & Germany & $\begin{array}{l}\text { Roche } 454 \\
\text { PyrosequencingV3 and V4 } \\
\text { regions of } 16 S \text { rDNA }\end{array}$ & [52] \\
\hline C. gigas & Homogenate & $\begin{array}{l}\text { Proteobacteria, } \\
\text { Fusobacteria, } \\
\text { Bacteroidetes }\end{array}$ & $\begin{array}{l}\text { Spirochaetes, } \\
\text { Cyanobacteria, Tenericutes, } \\
\text { Planctomycetes, } \\
\text { Verrucomicrobia, Firmicutes }\end{array}$ & $\begin{array}{l}\text { Tasmania, } \\
\text { Australia }\end{array}$ & 16S rDNA cloning & {$[60]$} \\
\hline C. virginica & $\begin{array}{l}\text { Stomach and gut } \\
\text { (intestine) tissue }\end{array}$ & $\begin{array}{l}\text { Mollicutes, } \\
\text { Planctomyctes, }\end{array}$ & $\begin{array}{l}\text { Actinobacteria, } \\
\text { Bacteroidetes, Deinococcus- }\end{array}$ & $\begin{array}{l}\text { Louisiana, } \\
\text { USA }\end{array}$ & $\begin{array}{l}\text { Roche 454Pyrosequencing } \\
\text { of } 16 \mathrm{~S} \text { rDNA }\end{array}$ & [6] \\
\hline
\end{tabular}


Li et al.; MRJI, 20(5): 1-14, 2017; Article no.MRJI.33842

\begin{tabular}{|c|c|c|c|c|c|c|}
\hline $\begin{array}{l}\text { Oyster } \\
\text { species }\end{array}$ & Tissue types & $\begin{array}{l}\text { High abundance } \\
\text { phyla }\end{array}$ & Low abundance phyla & Location & Identification methods & References \\
\hline & & $\begin{array}{l}\text { Chloroflexi, } \\
\text { Firmicutes, } \\
\text { Proteobacteria, } \\
\text { Verrucomicrobia, }\end{array}$ & $\begin{array}{l}\text { Thermus, Fusobacteria, } \\
\text { Spirochaete, Crenarchaea, } \\
\text { Euryarchaea }\end{array}$ & & & \\
\hline $\begin{array}{l}\text { C. gigas } \\
\text { C. corteziensis }\end{array}$ & $\begin{array}{l}\text { Depurated postlarvae } \\
\text { homogenate } \\
\text { Depurated juvenile } \\
\text { and adult oyster } \\
\text { gastrointestinal } \\
\text { tissues }\end{array}$ & $\begin{array}{l}\text { Proteobacteria, } \\
\text { Firmicutes }\end{array}$ & Spirochaetes, Actinobacteria & Mexico & $\begin{array}{l}\text { 16S rDNA PCR amplification } \\
\text { and TGGE analysis }\end{array}$ & {$[38]$} \\
\hline $\begin{array}{l}\text { C. pacifica } \\
\text { C. savignyi }\end{array}$ & Gill tissue & Proteobacteria & - & Israel & 16S rDNA cloning & [5] \\
\hline S. glomerata & $\begin{array}{l}\text { Adult oyster digestive } \\
\text { glands }\end{array}$ & $\begin{array}{l}\text { Firmicutes, } \\
\text { Proteobacteria, } \\
\text { Cyanobacteria, } \\
\text { Spirocheates }\end{array}$ & $\begin{array}{l}\text { Actinobacteria, Chloroflexi, } \\
\text { Chlorophyta }\end{array}$ & $\begin{array}{l}\text { Queensland, } \\
\text { Australia }\end{array}$ & 16S rDNA cloning & [36] \\
\hline C. iredalei & Homogenate & Proteobacteria & - & Malaysia & $\begin{array}{l}\text { Culturing methods using } \\
\text { universal and selective } \\
\text { medium plates }\end{array}$ & [4] \\
\hline C. gigas & $\begin{array}{l}\text { Gill tissue, gonads } \\
\text { and digestive glands }\end{array}$ & Proteobacteria & - & Mexico & $\begin{array}{l}\text { 16S rDNA PCR amplification } \\
\text { and fluorescent in situ } \\
\text { hybridization } \\
\text { (FISH) }\end{array}$ & [43] \\
\hline T. chilensis & Homogenate & Proteobacteria & - & Chile & 16S rDNA cloning & [3] \\
\hline O. edulis & Homogenate & Proteobacteria & - & $\begin{array}{l}\text { Mediterranean } \\
\text { Spanish } \\
\text { coast, Spain }\end{array}$ & $\begin{array}{l}\text { Culturing methods using } \\
\text { Marine Agar plates and } \\
\text { TCBS plates, and } \\
\text { hybridization with } \\
\text { phylogenetic probes }\end{array}$ & [42] \\
\hline
\end{tabular}


Additionally, oyster microbiota can also be analyzed from oyster homogenate, which provides an overall microbial composition in oyster samples (Table 1). Despite the cause of potential over-estimation of bacterial diversity of oyster microbiota, oyster homogenate has been used for routine environmental laboratory testing to detect certain microbes via standardized procedures. For example, oyster homogenate has been used for detecting Vibrio spp. in oyster samples according to FDA Bacteriological Analytical Manual (BAM) method [57], which has been used as a standard protocol to monitor Vibrio spp. concentrations in public health laboratories. Each oyster homogenate sample is usually collected from combining several individual oysters, thus providing an approach for monitoring microbiome variations from an oyster population in a growing site through seasonal changes. In summary, due its relative accuracy, simplicity, and popularity, using oyster homogenate for oyster microbiota studies could be a standard and simplified procedure for research laboratories to study and compare the microbial differences in diverse oyster growing areas.

As mentioned previously, multiple genomic analysis tools have been used to identify oyster microbiota (more detailed discussion following in section 7). For example, PCR-based nextgeneration sequencing (NGS) via the $16 \mathrm{~S}$ rDNA metagenomics approach have been widely used, however, the shotgun metagenomic sequencing method to detect oyster microbiota still remains a challenge. This is due to the difficulty in separating all microbes from blended oyster tissue cells, and microbial DNA extracted from oyster samples usually contain a large amount of host DNA. A possible method to overcome this difficulty can be achieved by removing oyster hemocytes from microbial cells through filtration using $0.2 \mu \mathrm{m}$ filters. This could lead to the possible application of shotgun metagenomic sequencing to study microbial taxonomy as well as functional gene compositions in oyster microbiota.

\section{DYNAMIC OYSTER MICROBIOTA UNDER DIFFERENT CONDITIONS}

Microbiota found in oysters are dynamic and can be affected by many factors including oyster growth stages, water column fluctuations, temperature changes, host immune response and infectious processes [6,9,10,38,56-59]. Analyzing ever-changing dynamics within oyster microbiota could help to provide insight into how oyster microbial community changes in response to environmental fluctuations, as well as correlating these changes to assist in the prevention of disease outbreaks.

Oyster microbial taxonomic compositions can change in different growth stages of life. Microbiota at the post-larval stage were found to be more diverse than those founded in the adult stage based on the results of ecological diversity measurements such as Chao1, ShannonWeaver $\left(\mathrm{H}^{\prime}\right)$, and Simpson index [9]. Post-larval oyster microbiota could undergo certain changes when juvenile oysters were relocated to grow-out sites, based on the principal component analysis of $16 \mathrm{~S}$ rDNA gene RFLP patterns [38]. The relative abundance of identified bacterial taxa indicated that oysters originated from the same post-larval hatchery could have a different microbiota composition if they grew up in different grow-out sites [9]. This phenomenon could be explained by the variability of nutrient sources that were available to the growth of oyster hatcheries in different grow-out sites. Thus, monitoring microbial changes in the same batch of oysters growing in different geographic areas could be helpful to discover potential core microbiota.

Temperature is another influential factor on the composition of microbiota in oysters. A study by Lokmer et al. showed that the microbial dynamics and composition in healthy oysters could be significantly affected by temperature stress [10]. Another study indicated that temperature could change the oyster microbiota composition through regulation of the population of oyster dominant and temperature-sensitive bacteria such as Mycoplasma [52]. In addition to Mycoplasma, Vibrio populations in oysters could also be influenced by temperature, leading to the fluctuation of oyster microbiota [56].

Once oysters are harvested from their growing sites, their microbiota composition could be affected by storage conditions as well. Fernandez-Piquer et al. [60] reported that storage temperature could influence bacterial diversity in postharvest $C$. gigas. A spoilage experiment utilizing the oyster species, $C$. gigas and $S$. glomerata, indicated that Proteobacteria became abundant in which Pseudoalteromonas and Vibrio found to be dominant in both oyster species at $4^{\circ} \mathrm{C}$ after seven days of storage [8]. In addition to the storage temperature, other postharvest treatments, such as depuration, high-pressure treatment, and quick freeze 
storage, could also influence the oyster microbiota $[9,61]$. Thus, understanding the oyster microbiota changes in the post-harvest process could be especially crucial in the surveillance of public health and prevention of food-related outbreaks.

\section{AVAILABLE TOOLS TO STUDY OYSTER MICROBIOTA}

Traditional methods of analyzing microbial communities include isolating bacterial strains using medium plates, counting colony forming units (CFU) on plates or using the most probable number (MPN) method, and analyzing microbial morphology using light and electron microscopy techniques [62-64]. For example, counting of the total number of CFU on Tryptic Soy Agar (TSA) plates can provide the rough estimation of particular bacterial strains grown in oysters [63]. Some cultivatable heterotrophic marine bacteria such as Vibrio spp. can also be isolated on marine Agar plates [42]. Specifically, Vibrio spp. such as $V$. splendidus and $V$. harveyi. can be isolated on the Vibrio selective Thiosulfate Citrate Bile Salts Sucrose (TCBS) Agar plates $[28,63]$. These methods are widely used in public health labs for oyster surveillance due to the relatively low cost and ease of utilization by lab technicians. Modifications of these traditional methods, such as applications of automated systems and newer selective media, could potentially be valuable for reducing the intensity of labor in public health laboratories. However, oyster surveillance studies are strongly influenced by weather and season (most of the studies are conducted during the summer), thus, limited usage time and high financial costs of automated systems limits their usage in smaller regional public health laboratories.

Even with readily available laboratory techniques used to cultivate bacteria, only less than $0.01 \%$ of the total bacteria in oysters are able to be cultivated $[3,65]$. Therefore, it is necessary to develop culture-independent methods for identifying unknown bacteria in oyster microbial communities. In the last few decades, the $16 \mathrm{~S}$ rDNA gene sequence analysis has been used to determine bacterial phylogenetic relationships [66]. Several methods have been applied in oyster bacteria sequencing based on the PCR amplification of $16 \mathrm{~S}$ rDNA gene. These methods include fluorescent in situ hybridization (FISH) [43], 16S rDNA gene cloning, and Sanger sequencing $[3,38,60]$. The microbial population polymorphisms of $16 \mathrm{~S}$ rDNA genes can also be analyzed by 16S rDNA based fingerprint methods including terminal restriction fragment length polymorphism (T-RFLP) analysis [60,67], temperature gradient gel electrophoresis (TGGE) [38], and denaturing gradient gel electrophoresis (DGGE) $[44,68]$. Of all the applications to advance from the use of the 16S rDNA gene, the most commonly used methods are 16S rDNA gene cloning and T-RFLP analysis. Although both methods are able to provide information on 16S gene sequence, there are limitations associated with these methods. The 16S rDNA gene cloning method could provide detailed bacterial taxonomy information with the amplification and sequencing of the full-length $16 S$ gene, but it could only identify limited number of clones due to the cost of Sanger sequencing. On the other hand, the T-RFLP method could reveal whole community profiles cost-effectively but not be able to identify individual OTUs. Despite the high accuracy of these methods, they are mainly used for research purpose due to relatively high costs and the needs of well-trained lab technicians to utilize the techniques. As a result, these methods are useful tools for advancements in oyster research laboratories, but are not perfectly suitable for the public health laboratory in public health surveillance. For public health surveillance purposes, developing 16S rDNA gene based microarray techniques could be more valuable and practical if the cost is affordable for the small public health laboratories globally.

In the past few years, the development of NGS techniques has been used to study oyster microbiota. Recently, longer and more accurate sequencing reads have been achieved [69]. The latest Roche 454 pyrosequencing platform GS FLX+ System can produce 1 million copies of 1,000-bp reads in length [69]. The Illumina MiSeq platform can produce 25 million copies of $2 \times 300$ bp reads using the $600 \mathrm{v} 3$ kit. These highthroughput sequencing instruments can explore microbiota in much deeper depth by producing millions of OTUs per sample, compared to the traditional 16S rDNA cloning method that could usually obtain 100 clones per sample with an upper-limit of approximately 1000 clones [70,71]. The drawback of this new technique is that only a small fraction of the full-length 16S rDNA gene can be sequenced due to the short sequencing read length, which could hinder the detection of microbes at the species level. Despite this limitation, bacterial classification at higher taxonomic ranks could be easily identified and the relative abundance of bacteria within each 
microbiome can be analyzed more accurately based on millions of OTUs (Table 1), which introduces a huge advance in studying oyster microbiota. Specifically, the PacBio $3^{\text {rd }}$ generation sequencing platform could provide full-length 16S rDNA gene sequences, but its high cost restricts its usage only in well financially supported laboratories and scientific communities.

The rapid improvement of metagenomic analytical methods could provide for an increase in approaches to study oyster microbiota. Different primer sets have been developed and evaluated in sequencing different regions of the $16 S$ rDNA gene [72]. The development of the Earth Microbiome Project and Human Microbiome Project has yielded many protocols and analytical methods [73,74]. New 16S rDNA primers have been developed to accommodate new sequencing platforms [75]. Several metagenomic analytical pipelines have been developed, such as CloVR [76], QIIME [77], Mothur [78], MG-RAST [79] and MetAMOS [80]. The NGS sequencer Roche 454 pyrosequencing platforms have been applied to decipher oyster microbiota using 16S rDNA gene metagenomic methods $[6,8-10,25]$. The popular Illumina MiSeq sequencer (San Diego, CA) has also been used in many $16 \mathrm{~S}$ rDNA-based aquatic metagenomic studies $[81,82]$, which could possibly be used for analyzing oyster microbiota. Furthermore, as the MiSeq sequencer has been used in public health laboratories for bacterial whole genome sequencing, implementation of the 16S rDNA based oyster microbiota analysis would be applicable in the near future. Thus, developing standardized protocols to be used across different laboratories would be necessary for comparing sequencing results. More specifically, easy-to-use analytical tools are needed for public health laboratories capable of detecting small amount of pathogenic bacteria from a large bacterial population in oyster microbiota using the 16S rDNA metagenomic method. In addition to the 16S rDNA gene sequences, using a shotgun metagenomic approach to monitor oyster microbiota would generate more genomic information on functional genes (such as Vibrio specific genes and other toxin genes), which can be a potential benefit of using this method. However, the shotgun method remains a challenge due to the need for high-throughput sequencing platforms larger than MiSeq and other new methods in order to remove oyster host DNA from sequencing samples.

\section{FUTURE PERSPECTIVES}

Although some oyster microbiota have been extensively studied with the development of metagenomic analytic techniques, the majority of their functions to their host oysters remains to be discovered. Elucidating dynamic oyster microbiota using NGS techniques and statistical models could help to monitor microbiome fluctuations, which could benefit the oyster industry and prevention of oyster-related food outbreaks. Future challenges may also include defining and further classifying core microbiota from different oyster species in different growing regions using both $16 \mathrm{~S}$ rDNA and shotgun metagenomic sequencing methods. In addition, oysters are an effective transmission vehicle of other pathogens such as Cryptosporidium, Giardia, Enterovirus and Norovirus that can infect humans and lead to human diseases [83-85]. With this mind, studying the potential transmission of pathogens from oysters to human might also be valuable for public health surveillance and consideration.

\section{CONCLUSION}

In conclusion, microbiota from different oyster species have been analyzed in recent studies and several major microbial taxa have been identified. Different oyster tissues may contain diverse microbial contents, which may be suitable for various applications. Oyster microbiota could change due to different growing stages and environmental conditions. New emerging genomic analytical technologies have provided more accurate solutions for analyzing an ever-changing oyster microbiota.

\section{ACKNOWLEDGEMENTS}

This project was supported in part by an appointment to the Research Participation Program at the Center for Food Safety and Applied Nutrition administration by the Oak Ridge Institute for Science and Education through an interagency agreement between the U.S. Department of Energy and the U.S. Food and Drug Administration.

\section{COMPETING INTERESTS}

Authors have declared that no competing interests exist. 


\section{REFERENCES}

1. Beck MW, Heck KL, Able KW, Childers DL, Eggleston DB, Gillanders BM, et al. The identification, conservation, and management of estuarine and marine nurseries for fish and invertebrates: A better understanding of the habitats that serve as nurseries for marine species and the factors that create site-specific variability in nursery quality will improve conservation and management of these areas. Bio Science. 2001;51:633-641.

2. Huvet $A$, Lapègue $S$, Magoulas $A$, Boudry $P$. Mitochondrial and nuclear DNA phylogeography of Crassostrea angulata, the Portuguese oyster endangered in Europe. Conserv Genet. 2000;1:251-262. DOI: 10.1023/a:1011505805923

3. Romero J, Garcia-Varela M, Laclette JP, Espejo RT. Bacterial 16S rRNA gene analysis revealed that bacteria related to Arcobacter spp. constitute an abundant and common component of the oyster microbiota (Tiostrea chilensis). Microb Ecol. 2002;44:365-371.

DOI: 10.1007/s00248-002-1063-7

4. Najiah $M$, Nadirah $M$, Lee KL, Lee SW, Wendy $\mathrm{W}$, Ruhil $\mathrm{HH}$, et al. Bacteria flora and heavy metals in cultivated oysters Crassostrea iredalei of Setiu Wetland, East Coast Peninsular Malaysia. Vet Res Commun. 2008;32:377-381.

DOI: 10.1007/s11259-008-9045-y

5. Zurel D, Benayahu Y, Or A, Kovacs A, Gophna U. Composition and dynamics of the gill microbiota of an invasive IndoPacific oyster in the eastern Mediterranean Sea. Environ Microbiol. 2011;13:14671476.

DOI: 10.1111/j.1462-2920.2011.02448.x

6. King GM, Judd C, Kuske CR, Smith C. Analysis of stomach and gut microbiomes of the eastern oyster (Crassostrea virginica) from coastal Louisiana, USA. PLoS One. 2012;7:e51475.

DOI: 10.1371/journal.pone.0051475

7. Ronquillo JD, Fraser J, McConkey AJ. Effect of mixed microalgal diets on growth and polyunsaturated fatty acid profile of European oyster (Ostrea edulis) juveniles. Aquaculture. 2012;360-361:64-68.

DOI:http://dx.doi.org/10.1016/j.aquaculture. 2012.07.018

8. Madigan TL, Bott NJ, Torok VA, Percy NJ, Carragher JF, de Barros Lopes MA, et al. A microbial spoilage profile of half shell
Pacific oysters (Crassostrea gigas) and Sydney rock oysters (Saccostrea glomerata). Food Microbiol. 2014;38:219227.

DOI: 10.1016/j.fm.2013.09.005

9. Trabal Fernández N, Mazon-Suastegui JM, Vazquez-Juarez $R$, Ascencio-Valle $F$, Romero J. Changes in the composition and diversity of the bacterial microbiota associated with oysters (Crassostrea corteziensis, Crassostrea gigas and Crassostrea sikamea) during commercial production. FEMS Microbiol Ecol. 2014;88:69-83.

DOI: $10.1111 / 1574-6941.12270$

10. Lokmer A, Mathias Wegner K. Hemolymph microbiome of pacific oysters in response to temperature, temperature stress and infection. ISME J. 2015;9:670-682.

DOI: 10.1038/ismej.2014.160

11. Harris J. Aquatic invasive species profile: Pacific oyster, Crassostrea gigas (Thunberg, 1793); 2008.

(Accessed 18 April 2017)

Available:http://depts.washington.edu/olde nlab/wordpress/wpcontent/uploads/2013/02/Crassostreagigas Harris.pdf

12. Imai $\mathrm{T}$, Numachi $\mathrm{K}$, Oizumi $\mathrm{J}$, Sato $\mathrm{S}$. Studies on the mass mortality of the oyster in Matsushima Bay II. Search for cause of mass mortality and the possibility to prevent it by transplantation experiment. Bull Tohoku Teg Fish Res Lab. 1965; 25:27-38.

13. Mori $\mathrm{K}$, Tamate $\mathrm{H}$, Imai $\mathrm{T}$, Itikawa $\mathrm{O}$. Studies on the mass mortality of the oyster in Matsushima Bay V. Changes in the metabolism of lipids and glycogen of the oyster during the stages of sexual maturation and spawning. Bull Tohoku Reg Fish Res Lab. 1965;25:65-88.

14. Beattie JH, Chew KK, Hershberger WK. Differential survival of selected strains of Pacific oysters (Crassostrea gigas) during summer mortality. Proc Natl Shellfish Assoc. 1980;70:184-189.

15. Cheney D, Elston R, Mac Donald B, Cherr G, Hamdoun A, Jacobsen J. An update on the ongoing oyster summer mortality study: Mortality of the pacific oyster, Crassostrea gigas: Health screening, environmental links and management options. J Shellfish Res. 2000;19:353-359.

16. Burge CA, Judah LR, Conquest LL, Griffin FJ, Cheney DP, Suhrbier A, et al. Summer seed mortality of the Pacific oyster, 
Crassostrea gigas Thunberg grown in Tomales Bay, California, USA: The influence of oyster stock, planting time, pathogens, and environmental stressors. $\mathrm{J}$ Shellfish Res. 2007;26:163-172.

DOI:10.2983/0730-

8000(2007)26[163:SSMOTP]2.0.CO;2

17. Fleury P, Goyard E, Mazurie J, Claude S, Bouget J, Langlade A, et al. The assessing of Pacific oyster (Crassostrea gigas) rearing performances by the IFREMER/REMORA network: Method and first results (1993-98) in Brittany (France). Hydrobiologia. 2001;465:195208.

18. Cotter E, Malham SK, O'Keeffe S, Lynch SA, Latchford JW, King JW, Beaumont AR, Culloty SC. Summer mortality of the Pacific oyster, Crassostrea gigas, in the Irish Sea: The influence of growth, biochemistry and gametogenesis. Aquaculture 2010;303:821.

19. Domeneghetti S, Varotto L, Civettini M, Rosani U, Stauder M, Pretto T, et al. Mortality occurrence and pathogen detection in Crassostrea gigas and Mytilus galloprovincialis close-growing in shallow waters (Goro lagoon, Italy). Fish Shellfish Immunol. 2014;41:37-44.

20. Burge CA, Griffin FJ, Friedman CS. Mortality and herpesvirus infections of the Pacific oyster Crassostrea gigas in Tomales Bay, California, USA. Dis Aquat Organ. 2006;72:31-43.

DOI: $10.3354 /$ dao072031

21. Soletchnik P, Lambert C, Costil K. Summer mortality of Crassostrea gigas (Thunberg) in relation to environmental rearing conditions. J Shellfish Res. 2005;24:197207.

22. Friedman CS, Estes RM, Stokes NA, Burge CA, Hargove JS, Barber BJ, et al. Herpes virus in juvenile Pacific oysters Crassostrea gigas from Tomales Bay, California, coincides with summer mortality episodes. Dis Aquat Organ. 2005;63:3341.

DOI: $10.3354 /$ dao063033

23. Petton B, Bruto $M$, James $A$, Labreuche $Y$, Alunno-Bruscia M, Le Roux F. Crassostrea gigas mortality in France: The usual suspect, a herpes virus, may not be the killer in this polymicrobial opportunistic disease. Front Microbiol. 2015;6:686.

DOI: 10.3389/fmicb.2015.00686

24. Le Roux F, Wegner KM, Polz MF. Oysters and Vibrios as a model for disease dynamics in wild animals. Trends Microbiol. 2016;24:568-580.

25. Chauhan A, Wafula D, Lewis DE, Pathak A. Metagenomic assessment of the eastern oyster-associated microbiota. Genome Announc. 2014;2:e01083-01014. DOI: 10.1128/genomeA.01083-14

26. Romalde JL, Barja JL. Bacteria in molluscs: Good and bad guys. In: MendezVilas, A (ed.) current research, technology and education topics in applied microbiology and microbial biotechnology. FORMATEX, Spain. 2010;136-147.

27. Renault T, Cochennec N. Chlamydia-like organisms in ctenidia and mantle cells of the Japanese oyster Crassostrea ggias from the French Atlantic coast. Dis Aquat Org. 1995;23:153-159.

28. Depaola A, Jones JL, Noe KE, Byars RH, Bowers JC. Survey of postharvestprocessed oysters in the United States for levels of Vibrio vulnificus and Vibrio parahaemolyticus. J Food Prot. 2009; 72:2110-2113.

29. DePaola A, Kaysner CA, Bowers J, Cook DW. Environmental investigations of Vibrio parahaemolyticus in oysters after outbreaks in Washington, Texas, and New York (1997 and 1998). Appl Environ Microbiol. 2000;66:4649-4654.

30. Daniels NA (2011) Vibrio vulnificus oysters: Pearls and perils. Clin Infect Dis. 2011;52:788-792.

DOI: $10.1093 / \mathrm{cid} / \mathrm{ciq} 251$

31. De Paola A, Jones JL, Woods J, Burkhardt W, ${ }^{\text {rd }}$, Calci KR, Krantz JA, et al. Bacterial and viral pathogens in live oysters: 2007 United States market survey. Appl Environ Microbiol. 2010;76:2754-2768.

DOI: 10.1128/AEM.02590-09

32. Morrison CM, Dial SM, Day WA, Joens LA. Investigations of Salmonella enterica serovar Newport Infections of oysters by using immunohistochemistry and knockout mutagenesis. Appl Environ Microbiol. 2012;78:2867-2873.

DOI: 10.1128/aem.07456-11

33. Rampersad FS, Laloo S, La Borde A, Maharaj K, Sookhai L, Teelucksingh J, et al. Microbial quality of oysters sold in Western Trinidad and potential health risk to consumers. Epidemiol Infect. 1999; 123:241-250.

34. Sayler GS, Nelson JD, Jr., Colwell RR. Role of bacteria in bioaccumulation of mercury in the oyster Crassostrea virginica. Appl Microbiol. 1975;30:91-96. 
35. Karim M, Zhao W, Rowley D, Nelson D, Gomez-Chiarri M. Probiotic strains for shellfish aquaculture: Protection of Eastern oyster, Crassostrea virginica, larvae and juveniles against bacterial challenge. J Shellfish Res. 2013;32:401-408.

DOI: 10.2983/035.032.0220

36. Green TJ, Barnes AC. Bacterial diversity of the digestive gland of Sydney rock oysters, Saccostrea glomerata infected with the paramyxean parasite, Marteilia sydneyi. J Appl Microbiol. 2010;109:613-622.

DOI: 10.1111/j.1365-2672.2010.04687.x

37. Boettcher KJ, Barber BJ, Singer JT. Additional evidence that juvenile oyster disease is caused by a member of the Roseobacter group and colonization of nonaffected animals by Stappia stellulatalike strains. Appl Environ Microbiol. 2000;66:3924-3930.

38. Trabal N, Mazon-Suastegui JM, VazquezJuarez R, Asencio-Valle F, MoralesBojorquez E, Romero J. Molecular analysis of bacterial microbiota associated with oysters (Crassostrea gigas and Crassostrea corteziensis) in different growth phases at two cultivation sites. Microb Ecol. 2012;64:555-569.

DOI: $10.1007 / \mathrm{s} 00248-012-0039-5$

39. Colwell RR, Liston J. Microbiology of shellfish. Bacteriological study of the natural flora of Pacific oysters (Crassostrea gigas). Appl Microbiol. 1960;8:104-109.

40. Murchelano RA, Brown C. Bacteriological study of the natural flora of the eastern oyster, Crassostrea virginica. J Invertebr Pathol. 1968;11:519-520.

41. Kueh CS, Chan Ky. Bacteria in bivalve shellfish with special reference to the oyster. J Appl Bacteriol. 1985;59:41-47.

42. Pujalte MJ, Ortigosa M, Macian MC, Garay E. Aerobic and facultative anaerobic heterotrophic bacteria associated to Mediterranean oysters and seawater. Int Microbiol. 1999;2:259-266.

43. Hernández-Zárate G, Olmos-Soto J. Identification of bacterial diversity in the oyster Crassostrea gigas by fluorescent in situ hybridization and polymerase chain reaction. J Appl Microbiol. 2006;100:664672.

DOI: 10.1111/j.1365-2672.2005.02800.x

44. Wang D, Zhang Q, Cui Y, Shi X. Seasonal dynamics and diversity of bacteria in retail oyster tissues. Int $\mathrm{J}$ Food Microbiol. 2014;173:14-20.

DOI: 10.1016/j.ijfoodmicro.2013.12.008
45. Ainsworth TD, Krause L, Bridge T, Torda G, Raina JB, Zakrzewski $M$, et al. The coral core microbiome identifies rare bacterial taxa as ubiquitous endosymbionts. ISME J. 2015;9:22612274.

46. Zehr JP, Jenkins BD, Short SM, Steward GF. Nitrogenase gene diversity and microbial community structure: A cross-system comparison. Environ. Microbiol. 2003;5:539-554.

47. Ivanova EP, Sawabe T, Alexeeva YV, Lysenko AM, Gorshkova NM, Hayashi K, et al. Pseudoalteromonas issachenkonii sp. Nov., a bacterium that degrades the thallus of the brown alga Fucus evanescens. Int J Syst Evol Microbiol. 2002;52:229-234.

48. Ivanova EP, Bakunina IY, Sawabe T, Hayashi K, Alexeeva YV, Zhukova NV, Nicolau DV, Zvaygintseva TN, Mikhailov VV. Two species of culturable bacteria associated with degradation of brown algae Fucus evanescens. Microb Ecol. 2002;43:242-249.

DOI: $10.1007 / \mathrm{s} 00248-001-1011-y$

49. Thomas F, Hehemann JH, Rebuffet $E$, Czjzek M, Michel G. Environmental and gut bacteroidetes: The food connection. Front Microbiol. 2011;2:93.

DOI: $10.3389 / \mathrm{fmicb} .2011 .00093$

50. Campa-Cordova AI, Luna-Gonzalez A, Mazon-Suastegui JM, Aguirre-Guzman G, Ascencio F, Gonzalez-Ocampo HA. Effect of probiotic bacteria on survival and growth of Cortez oyster larvae, Crassostrea corteziensis (Bivalvia: Ostreidae). Rev Biol Trop. 2011;59:183-191.

51. Galtsoff PS. The American oyster Crassostrea virginica Gmelin. Unites States department of the interior, Fishand wildlife service, Bureau of Commercial Fisheries; 1964.

52. Wegner KM, Volkenborn N, Peter H, Eiler A. Disturbance induced decoupling between host genetics and composition of the associated microbiome. BMC Microbiol. 2013;13:252.

DOI: $10.1186 / 1471-2180-13-252$

53. De Paola A, McLeroy S, McManus G. Distribution of Vibrio vulnificus phage in oyster tissues and other estuarine habitats. Appl Environ Microbiol. 1997;63:24642467.

54. Garnier M, Labreuche Y, Garcia C, Robert $M$, Nicolas JL. Evidence for the involvement of pathogenic bacteria in 
summer mortalities of the Pacific oyster Crassostrea gigas. Microb Ecol. 2007; 53:187-196.

DOI: 10.1007/s00248-006-9061-9

55. Wendling CC, Batista FM, Wegner KM. Persistence, seasonal dynamics and pathogenic potential of Vibrio communities from Pacific oyster hemolymph. PLoS One. 2014;9:e94256.

DOI: 10.1371/journal.pone.0094256

56. Schmitt $P$, Rosa RD, Duperthuy $M$, de Lorgeril J, Bachere E, DestoumieuxGarzon D. The antimicrobial defense of the pacific oyster, Crassostrea gigas. how diversity may compensate for scarcity in the regulation of resident/pathogenic microflora. Front Microbiol. 2012;3:160.

DOI: $10.3389 /$ fmicb.2012.00160

57. Kaysner CA, DePaola A, Jr. Vibrio, chapter 9. U.S. Food and Drug Administration, Washington, DC; 2004.

(Accessed April 2016)

Available:http://www.fda.gov/Food/FoodSci enceResearch/LaboratoryMethods/ucm07 0830.htm

58. Gerber GK. The dynamic microbiome. FEBS Lett. 2014;588:4131-4139.

DOI: 10.1016/j.febslet.2014.02.037

59. Faust K, Lahti L, Gonze D, de Vos WM, Raes J. Metagenomics meets time series analysis: unraveling microbial community dynamics. Curr Opin Microbiol. 2015;25: 56-66.

DOI: 10.1016/j.mib.2015.04.004

60. Fernandez-Piquer J, Bowman JP, Ross T, Tamplin ML. Molecular analysis of the bacterial communities in the live Pacific oyster (Crassostrea gigas) and the influence of postharvest temperature on its structure. J Appl Microbiol. 2012;112:11341143.

DOI: 10.1111/j.1365-2672.2012.05287.x

61. Prapaiwong N, Wallace RK, Arias CR. Bacterial loads and microbial composition in high pressure treated oysters during storage. Int J Food Microbiol. 2009;131: 145-150.

DOI: 10.1016/j.ijfoodmicro.2009.02.014

62. Choi DL, Choi HJ, Lee N-S, Park MS. First record of Mycoplasma-like organism in Pacific oyster (Crassostrea gigas) in Korea. J. Fish. Sci. Tech. 2003;6:135-139.

63. Aagesen AM, Häse CC. Seasonal effects of heat shock on bacterial populations, including artificial Vibrio parahaemolyticus exposure, in the Pacific oyster,
Crassostrea gigas. Food Microbiol. 2014; 38:93-103.

64. Chinnadurai S, Mohamed KS, Venkatesan V, Sharma J, Kripa V. Depuration of bacterial populations in the Indian backwater oyster Crassostrea madrasensis (Preston, 1916): Effects on surface and bottom held oysters. J Shellfish Res. 2014;33:409-414.

65. Romero J, Espejo R. The prevalence of noncultivable bacteria in oysters (Tiostrea chilensis, Phillippi, 1845). J Shellfish Res. 2001;20:1235-1240.

66. Woo P, Lau S, Teng J, Tse H, Yuen KY. Then and now: Use of 16S rDNA gene sequencing for bacterial identification and discovery of novel bacteria in clinical microbiology laboratories. Clin Microbiol Infect. 2008;14:908-934.

67. Pierce ML, Ward JE, Holohan BA, Zhao X, Hicks RE. The influence of site and season on the gut and pallial fluid microbial communities of the eastern oyster, Crassostrea virginica (Bivalvia, Ostreidae): community-level physiological profiling and genetic structure. Hydrobiologia. 2016; 765:97-113.

DOI: $10.1007 / \mathrm{s} 10750-015-2405-z$

68. La Valley KJ, Jones S, Gomez-Chiarri M, Dealteris J, Rice M. Bacterial community profiling of the Eastern Oyster (Crassostrea virginica): comparison of culture-dependent and culture-independent outcomes. J Shellfish Res. 2009;28:827835.

DOI: $10.2983 / 035.028 .0412$

69. Hodkinson BP, Grice EA. Next-generation sequencing: A review of technologies and tools for wound microbiome research. Adv. Wound Care. 2015;4:50-58.

70. Youssef N, Sheik CS, Krumholz LR, Najar FZ, Roe BA, Elshahed MS. Comparison of species richness estimates obtained using nearly complete fragments and simulated pyrosequencing-generated fragments in 16S rRNA gene-based environmental surveys. Appl Environ Microbiol. 2009; 75:5227-5236.

71. Degnan $\mathrm{PH}$, Ochman $\mathrm{H}$. Illumina-based analysis of microbial community diversity. ISME J. 2012;6:183-194.

72. Claesson MJ, Wang Q, O'Sullivan O, Greene-Diniz R, Cole JR, Ross RP, et al. Comparison of two next-generation sequencing technologies for resolving highly complex microbiota composition 
using tandem variable 16S rRNA gene regions. Nucleic Acids Res. 2010;38:e200. DOI: $10.1093 /$ nar/gkq873

73. Aagaard K, Petrosino J, Keitel W, Watson M, Katancik J, Garcia N, et al. The Human Microbiome Project strategy for comprehensive sampling of the human microbiome and why it matters. FASEB J. 2013;27:1012-1022.

DOI: 10.1096/fj.12-220806

74. Gilbert JA, Jansson JK, Knight R. The Earth Microbiome project: Successes and aspirations. BMC Biol. 2014;12:69.

DOI: 10.1186/s12915-014-0069-1

75. Klindworth A, Pruesse E, Schweer T, Peplies J, Quast C, Horn M, et al. Evaluation of general $16 \mathrm{~S}$ ribosomal RNA gene PCR primers for classical and nextgeneration sequencing-based diversity studies. Nucleic Acids Res. 2013;41:e110.1093/nar/gks1808.

DOI: 10.1093/nar/gks808

76. Angiuoli SV, Matalka M, Gussman A, Galens K, Vangala M, Riley DR, et al. CloVR: A virtual machine for automated and portable sequence analysis from the desktop using cloud computing. BMC Bioinformatics. 2011;12:356.

77. Caporaso JG, Kuczynski J, Stombaugh J, Bittinger K, Bushman FD, Costello EK, et al. QIIME allows analysis of highthroughput community sequencing data. Nat Methods. 2010;7:335-336.

DOI: 10.1038/nmeth.f.303

78. Schloss PD, Westcott SL, Ryabin T, Hall $J R$, Hartmann M, Hollister EB, et al. Introducing mothur: Open-source, platform-independent, communitysupported software for describing and comparing microbial communities. Appl Environ Microbiol. 2009;75:7537-7541. DOI: 10.1128/AEM.01541-09

79. Meyer F, Paarmann D, D'Souza M, Olson $R$, Glass EM, Kubal $M$, et al. The metagenomics RAST server-a public resource for the automatic phylogenetic and functional analysis of metagenomes. BMC Bioinformatics. 2008;9:386.

DOI: $10.1186 / 1471-2105-9-386$

80. Treangen TJ, Koren S, Sommer DD, Liu B, Astrovskaya I, Ondov B, et al. MetAMOS: A modular and open source metagenomic assembly and analysis pipeline. Genome Biol. 2013;14:R2.

DOI: $10.1186 / g b-2013-14-1-r 2$

81. Pfister CA, Gilbert JA, Gibbons SM. The role of macrobiota in structuring microbial communities along rocky shores. Peer J. 2014;2:e631.

DOI: $10.7717 /$ peerj.631

82. Manzari C, Fosso B, Marzano M, Annese A, Caprioli R, D'Erchia AM, et al. The influence of invasive jellyfish blooms on the aquatic microbiome in a coastal lagoon (Varano, SE Italy) detected by an Illuminabased deep sequencing strategy. Biol Invasions. 2015;17:923-940.

DOI: $10.1007 / \mathrm{s} 10530-014-0810-2$

83. Sutthikornchai C, Popruk S, Chumpolbanchorn K, Sukhumavasi W, Sukthana $Y$. Oyster is an effective transmission vehicle for Cryptosporidium infection in human. Asian Pac J Trop Med. 2016;9(6):562-6.

DOI: 10.1016/j.apjtm.2016.04.018.

84. Schets FM1, van den Berg $\mathrm{HH}$, Engels GB, Lodder WJ, de Roda Husman AM. Cryptosporidium and Giardia in commercial and non-commercial oysters (Crassostrea gigas) and water from the Oosterschelde, The Netherlands. Int $\mathrm{J}$ Food Microbiol. 2007;113(2):189-94.

85. Shieh YC, Baric RS, Woods JW, Calci KR. Molecular surveillance of enterovirus and norwalk-like virus in oysters relocated to a municipal-sewage-impacted gulf estuary. Appl Environ Microbiol. 2003;69(12):7130-6.

(C) $2017 \mathrm{Li}$ et al.; This is an Open Access article distributed under the terms of the Creative Commons Attribution License (http://creativecommons.org/licenses/by/4.0), which permits unrestricted use, distribution, and reproduction in any medium, provided the original work is properly cited.

Peer-review history:

The peer review history for this paper can be accessed here: http://sciencedomain.org/review-history/19912 